\title{
PENGARUH BUDAYA ORGANISASI DAN KEPEMIMPINAN TERHADAP \\ LOYALITAS KARYAWAN \\ PADA PT PURNAMAJAYA BHAKTI UTAMA
}

Oleh : Sugiyarto, S.E, M.M.

Dosen Prodi Sekretari Universitas Pamulang

\section{Sugiyarto.harto@gmail.com}

\begin{abstract}
Abstrak
Budaya organisasi merupakan bauran dari asumsi, tingkah laku, cerita, mitos, metafora dan ide lainya yang digabung menjadi satu untuk menentukan apa arti bekerja dalam organisasi. Budaya organisasi tidak terlepas dari karakter manusia, lingkungan, dan kepentingan.

Membangun budaya organisasi tidak mudah dan dibutuhkan kepemimpin yang memiliki karakter yang kuat dalam membangun budaya kerja dan lingkungan kerja menjadi lebih efesien dan produktif. Tentunya harapan perusahaan dengan membaiknya budaya organisasi dan kepemimpinan yang kuat akan berpengaruh tehadap loyalitas karyawan terhadap peruasahaan Dampak secara langsung dari dua variable tersebut tentunya dengan adanya peningkatan kinerja individu dengan nyaman bekerja di dalam perusahaan.

Hasil penelitian dari korelasi sederhana antara budaya organisasi dengan loyalitas

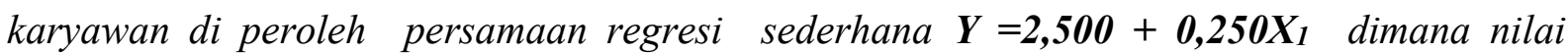
koefesien regeresi $\left(\boldsymbol{b}_{1}\right)$ hanya $\mathbf{0 , 2 5 0}$, artinya tidak ada pengaruh antara budaya organisasi terhadap loyalitas karyawan. Sedangkan dengan analisa koefesien korelasi parsial di peroleh dari variable budaya organisasi $\left(\boldsymbol{X}_{1}\right)$ sebesar $\mathbf{0 , 6 6 1}$, artinya secara parsial terdapat hubungan yang kuat antara budaya organisasi $\left(X_{1}\right)$ dengan Loyalitas $(Y)$. Dari hasil uiji hipotesis 1 dengan $\boldsymbol{\alpha}=\mathbf{0 , 0 5}$ di peroleh $\boldsymbol{t}$ hitung $(44,615)>\boldsymbol{t}$ table $(2,025)$, dengan demikian Ho di tolak, artinya terdapat hubungan parsial antara budaya organisasi $\left(\boldsymbol{X}_{\boldsymbol{1}}\right)$ dan loyalitas $(\boldsymbol{Y})$ dengan korelasi determinasi $\left(\boldsymbol{r}^{2}\right)$ sebesar $3,7 \%$.

Variabel kepemimpinan dari hasil analisa di peroleh persamaan regreasi $\boldsymbol{Y}=1,496+$

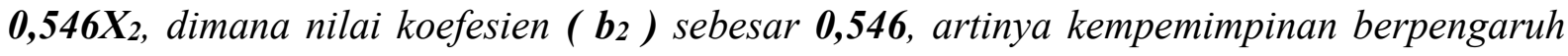
terhadap loyalitas dengan tingkat pengaruh sedang.

Untuk koefesien korelasi parsial variable kepemimpinan di ketahui hasilnya 0,224 (lemah). Dari hasil uji hipotesis 2 di peroleh $t$ hitung $(48,97)>t_{\text {tabel }}(2,025)$ Ho di tolak artinya
\end{abstract}


terdapat hubungan parsial antara kempemimpinan $\left(X_{2}\right)$ terhadap Loyalitas $(Y)$ dengan korelasi determinasi $\left(\boldsymbol{r}^{2}\right)$ sebesar $42,9 \%$

Dari hasil korelasi berganda antara budaya organisasi $\left(X_{1}\right)$ dan kepemimpinan $\left(X_{2}\right)$ secara bersama -sama terhadap loyalitas $(Y)$ di peroleh persamaan linier sebagai

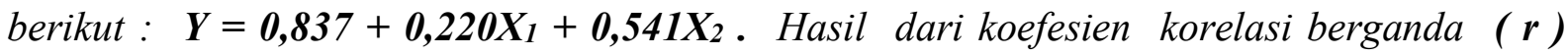
sebesar 0,676 sedangkan korelasi determinasi $\left(\boldsymbol{r}^{2}\right)$ sebesar 45,7\%. Dari hasil uji hipotesis 3 di ketahui $\boldsymbol{t}_{\text {hitung }}(\mathbf{5 , 4 2 6})>_{\boldsymbol{t}_{\text {tabel }}(2,024)}$ dan $\boldsymbol{F}_{\text {hitung }}(\mathbf{1 6 , 0 2 1})>_{\boldsymbol{F} \text { tabel }}(3,24)$. Dengan demikian Ho di tolak, artinya terdapat hubungan atau pengaruh antara budaya organisasi $\left(X_{1}\right)$ dan kepemimpinan $\left(X_{2}\right)$ secara bersama-sama terhadap loyalitas kayawan $(\boldsymbol{Y})$.

\section{Kata Kunci : Budaya Organisasi, Kepemimpinan, Loyalitas Karyawan}

\section{PENDAHULUAN}

\section{A. Latar Belakang Masalah}

Perusahaan merasakan bahwa persaingan usaha dari tahun ke tahun semakin meningkat dan sangat ketat, sementara loyalitas karyawan terhadap perusahaan dari tahun ke tahun semakin menurun. Hal ini bisa di lihat absensi karyawan, produktivitas karyawan dan masih adanya karyawan yang keluar atau pindah kerja ke perusahaan lain. Pada awal tahun 90-an banyak masyarakat mulai mebicarakan nilai nilai baru tentang budaya, konflik budaya dan bagaimana cara mempertahankan budaya tersebut.

Selain faktor budaya, gaya kepemimpinan seorang pemimpin dalam organisasi akan sangat menentukan arah dan tujuan organisasi itu sendiri. Dimana kemampuan pemimpin dalam mempengaruhi orang lain untuk mencapai tujuan organisasi dengan manajemen kepemimpinan yang efektif. Banyak pemimpin yang tidak tahu apa yang harus di lakukan supaya karyawan merasa nyaman di dalam lingkungan kerja

\section{B. Identifikasi masalah}

Dari permasalah di uraikan di atas, penulis mengidentifkasikan permasalahan sebagai bahan penelitian sebagai berikut :

1. Masih ada karyawan yang pindah kerja/tidak setia

2. Masih adanya karyawan tidak sungguh-sungguh dalam bekerja/tidak tulus 
3. Masih adanya karyawan tidak mentaati intruksi atasan

4. Kurang komunikasi antara karyawan dan atasan secara aktif.

\section{Perumusan Masalah}

Perusahaan atau organisasi sebagai tempat berkarya dan mengembangkan diri, tentu akan menjadi kebanggaan karyawan yang mampu menumbuhkan citra perusahaan yang baik dengan ditopang kepemimpinan yang mampu menjembatani antara karyawan dan manajemen. Tapi faktanya antara harapan dan kenyataan selalu berbeda, maka untuk mengehui hal tersebut di perlukan penelitian verifikatif dengan melihat hubungan antara budaya organisasi dan kepemimpinan terhadap loyalitas karyawan.

Dari uraian di atas dapat dirumuskankan masalah sebagai berikut :

1. Mengapa masih banyak karyawan yang pindah kerja/tidak setia?

2. Apa penyebab karyawan sungguh-sungguh dalam bekerja / tidak tulus?

3. Kenapa masih adanya karyawan tidak mentaati intruksi atasan?

4. Hal-Hal apa sajakah yang menyebabkan kurang komunikasi antara karyawan dan atasan secara aktif.

\section{PEMBAHASAN}

\section{A. Pengertian Budaya Organisasi}

Menurut Mansyur Ramly ( 2014 ) dalam bukunya “ Kepemimpinan dan Perilaku Organisasi " dijelaskan bahwa secara umum budaya adalah sejumlah pemahaman penting terkait norma, nilai, sikap dan keyakinan yang di miliki bersama oleh anggota organisasi. Edgar Schein dalam Amin Widjaya ( 2004 : 17 ) mendefinisikan budaya oragnisai adalah suatu pola asumsi dasar yang di miliki bersama yang di dapat oleh suatu kelompok ketika memecahkan masalah penyesuaian eksternal dan internal yang telah berhasil dan di ajarkan kepada anggota baru sebagai cara yang tepat untuk menerima, berfikir dan merasa berhubungan dengan masalah tersebut.

Talizidu Ndraha dalam bukunya Budaya Organisasi ( 1997;11,33 ) di jelaskan bahwa budaya organisasi tidak terlepas dari aspek manusia, lingkungan, kebutuhan dan kepentingan. 
Menurut Robbin P Stepthen ( $1996: 438$ ) budaya organisasi adalah sebuah system yang terbentuk akibat persamaan makna dan persepsi yang di anut bersama oleh anggota perusahaan, di mana, dimana budaya organisasi berperan sebagai pembeda antara perusahaan yang satu dengan yang lainnya.

\section{Fungsi budaya Organisasi}

Ada 4 macam fungsi budaya organisasi menurut J Winardi ( $2003: 215$ )
a. Sebagai identitas organisasi
b. Sebagai Stabilitas Sistem social
c. Sebagai komitmen kolektif
d. Sebagai alat yang menimbulkan kepekaan

\section{Faktor-Faktor Budaya Organisasi}

Menurut Kisdarto Atmosoeputro ( $2001 ; 71$ - 72 ) budaya organisasi terbentuk dari beberapa unsur :
a. Lingkungan usaha
b. Nilai - nilai
c. Panutan atau keteladanan
d. Jaringan

Menurut J Winardi, ( $2003 ; 212$ ) kultur suatu organisasi mencakup :
a. Pola dan perilaku yang di terima dan di akui
b. Norma - norma
c. Sasaran organisai
d. Teknologi yang di gunakan

Menurut hasil riset J.A Chatman dan K.A Jhon dalam Amin Widjaya Tunggal ( $2004: 1-2$ ) ada tujuh dimensi dalam budaya organisasi :
a. Inovasi dan pengambilan resiko yaitu sejauh mana karyawan di dorong untuk inovatif dan mengambil keputusan
b. Perhatian dan rincian yaitu sejauh mana karyawan di harapkan memperlihatkan kecermatan analisis dan detail


c. Orientasi hasil yaitu sejauh mana manajemen memfokuskan pada hasil bukanya pada teknik dan proses yang di gunakan untuk mencapai hasil

d. Orientasi orang yaitu sejauh mana keputusan manajemen memperhitungkan efek terhadap individu yang ada di dalam oragnisasi

e. Orientasi tim yaitu sejauh mana kegiatan kerja di organisasikan sekitar tim, bukan individu.

f. Keagresifan, yaitu sejauh mana karyawan itu agresif dan kompetitif dan tidak santai

g. Kemantapan yaitu sejauh mana kegiatan organisasi menekankan selalu tumbuh.

\section{B. Pengertian Kepemimpinan}

Kepemimpinan adalah kemampuan seseorang di dalam mempengaruhi orang lain untuk mencapai tujuan organisai yang telah di tetapkan. Menurut Soebagio Sastrodiningrat, ( $2002 ; 14-16$ ), kepemimpinan memiliki definisi :

1. Kepemimpinan adalah proses mempengaruhi kegiatan kelompok menuju kea rah penentuan tujuan dan mancapai tujuan.

2. Kepemimpinan adalah proses di mana seseorang berusaha menggunakan pengaruh kemasyarakatan terhadap anggota suatu kelompok

3. Kepemimpinan adalah proses pengaruh antar personal yang di laksanakan dalam suatu keadaan yang di tujukan untuk mencapai suatu tujuan khusus melalui proses komunikasi.

4. Kepemimpinan adalah proses dimana seorang pelaksana memberi petunjuk, pengaruh, pembinaan, atau mempengaruhi pekerjaan orang lain untuk mencapai tujuan yang telah di tetapkan.

Esensi kempemimpinan menurut Soebagio Sastrodiningrat :

1. Adanya kemampuan mempengaruhi

2. Adanya orang yang di pengaruhi

3. Memiliki tujuan

4. Adanya batasan waktu.

\section{Fungsi Kepemimpinan}

Menurut R.L Kkonh dan Hrai dalam Heidji Rahman ( 1990 : 218 ). Menjelaskan bahwa fungsi seorang pemimpin adalah :

1. Memberikan keputusan terhadap kebutuhan para bawahan 
2. Menyusun jalur dan memberikan pedoman untuk mencapai tujuan perusahaan

3. Menghilangkan hambatan - hambatan

4. Mengubah tujuan karyawan agar bermanfaat secara oragnisasi.

\section{Dimensi Kepemimpinan}

\section{Kemampauan Dalam Mengambil Keputusan}

Menurut Djoko Santoso, ( 2003 : 1230 ) bahwa kompetensi kemampuan adalah kecakapan untuk melaksanakan tugas kepemimpinan dengan sukses Tugas utama pemimpin adalah mengambil keputusan secara efesien, efektif, cepat dan tepat. Maka untuk melakukan hal tersebut pemimpin harus memiliki ;
a. Kecakapan teknis
b. Kecakapan Skill atau konsep skill
c. Kecakapan spiritual

\section{Kemampuan Berkomunikasi}

Menurut Kennet dan Gary ( 1992 ) dalam Husein Umar ( 2000:25), komunikasi dapat di definisikan sebagai penyampaian informasi antara dua orang atau lebih yang juga meliputi pertukaran informasi antar manusia dan mesin. Menurut Husein Umar ( $2000: 26$ ) efektifitas komunikasi komunikasi meliputi :

a. Keterbuakaan, yaitu keinginan untuk terbuka dan menanggapi secara jujur lawan bicara.

b. Emapati, artinya mencoba merasakan perasaan yang sama dengan lawan bicara

c. Dukungan, yaitu mencoba untuk tidak mengkritik atau menyerang isi pembicaraan, akan tetapi mendukung isi pembicaraan walau hanya sekedar mengangguk.

d. Kepositifan yaitu selalu menjaga perasaan positif terhadap orang lain.

e. Kesamaan yaitu karena semua manusia tidak sama, maka komunikasi semakin lebih efektif.

\section{Kemampuan Memotivasi}

Menurut Teori X dan Y Mc Gregor, di jelaskan bahwa manusia yang menganut teori $\mathrm{X}$ pada dasarnya manusia atau pekerja itu malas, maka pemimpin harus mampu memberikan motivasi dan mengarahkan 
Teori Y memandang bahwa setiap orang pada dasarnya baik dan rajin bekerja, sehingga pemimpin lebih banyak medelegasikan pekerjaan kepada mereka.

Sedangkan menurut Abraham Maslow lebih banyak meniliti motivasi dari segi urutan prioritas kebutuhan dalam manusia dalam memenuhi kebutuhan hidupnya di mulai dari yang paling mendasar yaitu kebutuhan fisiologis ( kelangsungan hidup, sandang pangan, rasa aman, rasa memiliki, harag diri dan aktualisasi diri ) secara pirmidal.

\section{Kemampuan memimpin}

Menurut W Bennis ( 1997 : 78 ) di jelaskan bahwa empat bidang kompetensi kepemimpinan :

a. Kemampauan mengelola orang atau pengikutnya

b. Kemampuan menyampaikan maksud dan mengkomunikasikan visi dan misi dan sasaran atau target yang akan di capai.

c. Kemampuan mengelola kepercayaan.

d. Mengenali berbagai kelebihan, kekuatan dan kecakapan oanggotanya dan di manfaatkan secara efektif.

\section{E. Pengertian Loyalitas}

Menurut kamus Bahasa Indonesia modern M. Dahlan Yacuk Al Bari (2004) Loyalitas memiliki pengertian kesetiaan, ketaatan, ketulusan.

Sedangkan menurut beberapa ahli manajemen, Loyalitas adalah suatu sikap yang di tunjukan oleh anggota organisasi terhadap manajemen perusahaan secara kongret membuat sebagian besar anggota organisasi mendapat manfaat dari manajemen.

Menurut Triantoro Safaria ( 2004 ), setiap perusahaan memiliki budaya yang berbeda-beda, sehingga pemimpin harus memahami budaya perusahaan di tempatnya bekerja, sehingga peranan kepemimpinan dan budaya organisasi akan mampu meningktakn loyalitas karyawan, yang pada akhirnya akan meningkatkan kinerja perusahaan secara keseluruhan. 


\section{F. Analisa Data}

\section{Budaya Organisasi ( $\left.X_{1}\right)$ terhadap Loyalitas Karayawan ( $Y$ )}

Untuk menggetahui pengaruh antara variabel prediktor $\left(\mathrm{X}_{1}\right)$ budaya organisasi terhadap variabel respon yaitu loyalitas ( Y ).

Pengujian di lakukan dengan analisis korelasi regresi linier sederhana dengan menggunakan software SPSS 13.

\section{a. Analisa Regresi Linier Sederhana : $Y=F(X)$}

$\mathbf{Y}=\mathbf{a}+\mathbf{b}_{1} \mathbf{x}_{1}$

Dimana $a$ dan $b$ adalah konstanta yang bisa di hitung dengan kuadrat terkecil dengan bantuan SPSS 13 dapat lihat pada table coeffecients ${ }^{\mathrm{a}}$ untuk nilai ( a ) = 2,500 , sedangkan nilai koefesien regersi $\left(b_{1}\right)=0,250$

Maka $\mathrm{Y}=2,500+0,250 \mathrm{X}_{1}$

Karena nilai koefesien regresi (b1) hanya 0,250 artinya budaya organisasi tidak berpengaruh terhadap loyalitas karyawan

\section{b. Analisa Koefesien Korelasi Parsial ( $r \mathrm{X}_{1} \mathbf{Y}$ )}

Korelasi parsial adalah korelasi terpisah dari dua variabel atau lebih, dengan menggunakan formula korelasi person dengan bantuan sofatware SPSS 13 dapat di ketahui nilai korelasi parsial untuk variabel budaya organisasi $\left(\mathrm{X}_{1}\right)$ sebesar 0,661 .

Berikut adalah table Koefesien korelasi ( $r$ ) derajat hubungan/korelasi menurut Suharsini Aritkunto ( $1997: 260$ ) sebagai berikut :

\begin{tabular}{|c|c|}
\hline Interval Koefesien & Tingkat Hubungan \\
\hline $0,02-0,119$ & Rendah atau sangat lemah \\
\hline $0,20-0,399$ & Lemah \\
\hline $0,40-0,599$ & Sedang \\
\hline $0,60-0,799$ & Kuat \\
\hline $0,80-1,000$ & Sangat Kuat \\
\hline
\end{tabular}

c. Pengujian Hipotesis 1 Korelasi Parsial Budaya Organisasi $\left(X_{I}\right)$ terhadap Loyalitas Karyawan (Y)

Keterangan : (n) adalah jumlah responden, (k) adalah jumlah variabel bebas, (1) adalah variabel terikat 


$$
\begin{aligned}
& \mathrm{t}_{12(3)}=\mathrm{r}_{12(3)} \\
& \mathrm{t}_{12(3)}=0,661 \\
& \mathrm{t}_{\text {hitung }}=44,615
\end{aligned}
$$

Dengan menggunakan $\alpha=0,05$ dengan tingkat keyakinan 95\%, maka dapat $\mathrm{T}_{\text {hitung }}(44,615)>\mathrm{t}_{\text {tabel }}(2,025)$, dengan demikian Ho di tolak, artinya terdapat hubungan parsial antara variabel budaya organisasi dengan variabel loyalitas karyawan.

\section{d. Analisa Korelasi Determinasi $\left(r^{2}\right)$ Budaya Organisasi $\left(X_{I}\right)$ terhadap Loyalitas Karyawan (Y)}

Untuk mengetahui seberapa besar kontribusi pengaruh budaya organisasi terhadap loyalitas karyawan, maka dengan bantuan software SPSS 13, maka di ketahui hasilnya $\mathrm{r}^{2}$ adalah 0,037 . Dengan rumus manual $\mathrm{sbb}$ :

$$
\begin{aligned}
\mathrm{KD} & =\mathrm{r}^{2} \times 100 \% \\
& =0,193^{2} \times 100 \% \\
\mathrm{KD} & =3,7 \%
\end{aligned}
$$

Artinya budaya organisasi hanya memiliki kontribusi pengaruh sebesar 3,7\% terhadap loyalitas karyawan,sedangkan sisanya 96,3\% di pengaruhi oleh factor lain.

\section{Kepemimpinan ( $\left.\mathrm{X}_{2}\right)$ terhadap Loyalitas Karyawan ( $\mathrm{Y}$ )}

Untuk menggetahui pengaruh anatra variabel prediktor $\left(X_{2}\right)$ kepemimpinan terhadap variabel respon yaitu loyalitas ( Y ) .

Pengujian di lakukan dengan analisis korelasi regresi linier sederhana dengan menggunakan software SPSS 13

\section{a. Analisa Regresi Linier Sederhana : Y $=$ F ( X )}

$\mathbf{Y}=\mathbf{a}+\mathbf{b}_{2} \mathbf{x}_{2}$

Dimana $a$ dan $b$ adalah konstanta yang bisa dihitung dengan kuadrat terkecil dengan bantuan SPSS 13 dapat lihat pada table coeffecients ${ }^{\mathrm{a}}$ untuk nilai ( a ) = 1,496 , sedangkan nilai koefesien regersi $\left(b_{2}\right)=0,546$ 
Maka $\mathrm{Y}=1,496+0,546 \mathrm{X}_{2}$,

Karena nilai koefesien regresi $\left(b_{2}\right)$ hanya 0,250 artinya kepemimpinan berpengaruh terhadap loyalitas karyawan dengan tingkat pengaruhnya sedang.

\section{b. Analisa Koefesien Korelasi Parsial ( $r \mathbf{X}_{2} \mathbf{Y}$ )}

Korelasi parsial adalah korelasi terpisah dari dua variabel atau lebih, dengan menggunakan formula korelasi person dengan bantuan sofatware SPSS 13 dapat di ketahui nilai korelasi parsial untuk variabel kepemimpinan $\left(\mathrm{X}_{2}\right)$ sebesar 0,224

Berikut adalah table Koefesien korelasi ( $\mathrm{r}$ ) derajat hubungan /korelasi menurut Suharsini Aritkunto ( $1997: 260$ ) sebagai berikut :

\begin{tabular}{|c|c|}
\hline Interval Koefesien & Tingkat Hubungan \\
\hline $0,02-0,119$ & Rendah atau sangat lemah \\
\hline $0,20-0,399$ & Lemah \\
\hline $0,40-0,599$ & Sedang \\
\hline $0,60-0,799$ & Kuat \\
\hline $0,80-1,000$ & Sangat Kuat \\
\hline
\end{tabular}

\section{c. Pengujian Hipotesis 2 Korelasi Parsial Kepemimpinan $\left(X_{2}\right)$ terhadap Loyalitas Karyawan ( $Y)$}

Keterangan : (n) adalah jumlah responden, (k) adalah jumlah variabel bebas, (1) adalah variabel terikat

$$
\begin{array}{ll}
\mathrm{t}_{13(3)}=\mathrm{r}_{13(3)} & \sqrt{\frac{\mathrm{n}-\mathrm{k}-1}{1-\mathrm{r}_{13(3)}}} \\
\mathrm{t}_{13(3)}=0,224 & \sqrt{\frac{41-2-1}{1-0,224}} \\
\mathrm{t}_{\text {hitung }}=48,97
\end{array}
$$

Dengan menggunakan $\alpha=0,05$ dengan tingkat keyakinan 95\%, maka dapat $t_{\text {hitung }}(48,97)>t_{\text {tabel }}(2,025)$, dengan demikian Ho di tolak, artinya terdapat hubungan parsial antara variabel kepemimpinan dengan variabel loyalitas karyawan. 


\section{d. Analisa Korelasi Determinasi $\left(r^{2}\right)$ Kepemimpinan $\left(X_{2}\right)$ terhadap Loyalitas Karyawan (Y)}

Untuk mengetahui seberapa besar kontribusi pengaruh budaya organisasi terhadap loyalitas karyawan, maka dengan bantuan software SPSS 13, di ketahui hasilnya ${ }^{2}$ sebesar 0,429 .

Jika menggunakan rumus manual maka akan di peroleh angka yang sama

$$
\begin{aligned}
\mathrm{KD} & =\mathrm{r}^{2} \times 100 \% \\
& =0,655^{2} \times 100 \% \\
\mathbf{K D} & =\mathbf{4 2 , 9 \%}
\end{aligned}
$$

Artinya kepemimpinan memiliki kontribusi pengaruh sebesar 42,9\% terhadap loyalitas karyawan,sedangkan sisanya $57,1 \%$ di pengaruhi oleh factor lain.

\section{Pengaruh Budaya Organisasi dan Kepemimpinan terhadap Loyalitas Karyawan}

\section{a. Analisa Regresi berganda}

Untuk mengetahui pengaruh budaya organisasi $\left(\mathrm{X}_{1}\right)$ dan kepemimpinan $\left(\mathrm{X}_{2}\right)$ terhadap loyalitas karyawan (Y), maka di gunakan analisa statistic korelasi berganda dengan persamaan linier berikut ini :

$\mathrm{Y}=\mathrm{a}+\mathrm{b}_{1} \mathrm{X}_{1}+\mathrm{b}_{2} \mathrm{X}_{2}$

Berdasarkan hasil perhitungan dengan menggunakan software SPSS 13 di ketahui nilai :

1) Konstanta a sebesar 0,837

2) Nilai koefesien regresi b1 sebesar 0,220

3) Nilai koefesien regresi b2 sebesar 0,541

Dengan demikian akan di peroleh persamaan regresi berganda sebagai berikut: $\mathrm{Y}=0,837+0,220 \mathrm{X}_{1}+0,541 \mathrm{X}_{2}$

Dari persamaan di atas bisa di lihat bahwa ada pengaruh positif dari kedua variabel, artinya jika budaya organisasi dan kepemimpinan tidak di tingkatkan, maka loyalitas karyawan hanya 0,837 .

Jika budaya organisasi dan kepemimpinan secara bersama-sama di tambah satu satuan, maka loyalitas karayawan akan meningkat 0,220 satuan, karena variabel $\mathrm{X}_{1}$ dan sebesar 0,541 dikarenakan variabel $\mathrm{X}_{2}$ 


\section{b. Analisa Koefesien Korelasi Berganda ( $r$ )}

Untuk mengetahui tingkat hubungan antara variabel budaya organisasi dan kepemimpinan secara bersamaan terhadap loyalitas karyawan, maka dengan bantun software SPSS 13 dapat di ketahui nilai koefesien korelasi antara variabel $\mathrm{X}_{1}$ dan $\mathrm{X}_{2}$ secara bersama - sama terhadap variabel $\mathrm{Y}$ sebesar 0,676 , artinya terhadap hubungan yang kuat antara budaya organisasi dan kepemimpinan terhadap loyalitas karyawan.

\section{c. Analisa Korelasi Determinasi ( $\left.\mathbf{r}^{2}\right)$}

Dengan menggunakan software SPSS 13 bisa di ketahui berapa besar kontribusi budaya organisai dan kepemimpinan terhadap loyalitas karyawan, dengan korelasi determinasi $\left(\mathrm{r}^{2}\right)$ sebesar $45,7 \%$.

Sedangkan dengan rumus manual sebagai berikut :

$$
\begin{aligned}
\mathrm{KD} & =\mathrm{r}^{2} \times 100 \% \\
& =0,457^{2} \times 100 \% \\
\mathbf{K D} & =\mathbf{4 5 , 7} \%
\end{aligned}
$$

\section{d. Uji Hipotesis 3}

Dengan bantuan software SPSS 13 diketahui nilai $F_{\text {hitung }}(16,021)>F_{\text {tabel }}$ $(3,24)$, karena $F$ hitung lebih dari nilai $F$ tabel, maka Ho di tolak, artiny ada hubungan antara budaya organisasi dan kepeminpinan terhadap loyalitas karyawan.

Sedangkan dengan $U j i T$, dapat peroleh $t_{\text {hitung }}(5,426)>t_{\text {tabel }}(2,024)$, karena nilai $t$ hitung lebih besar dari $t$ table, maka Ho di tolak, artinya terbukti bahwa ada hubungan antara budaya organisasi dan kepemimpinan terhadapa loyalitas karyawan.

\section{KESIMPULAN}

Hasil penelitian menunjukan $87,8 \%$ karyawan menyatakan budaya organisasi perusahaan sudah baik dan sementara $12,2 \%$ karyawan yang menyatakan kurang baik . Terkait dengan kepemimpian dari hasil penenlitian menunjukan bahwa 87,2 \% karyawan 
menyatakan kepemimpinan saat ini sudah berjalan dengan baik, dan hanya $12,8 \%$ karyawan menyatakan kurang baik.

Budaya organisasi dan kempemimpinan secara bersama-sama mempengaruhi loyalitias karyawan sebesar $45,5 \%$.

Dengan budaya organisasi yang baik, kepemimpinan yang baik, ketulusan dalam bekerja, mengikiuti prosedur dan mengikuti perintah atasan dan bertanggung terhadap pekerjaan, maka akan tumbuh loyalitas karyawan yang baik..

\section{DAFTAR PUSTAKA}

J. Winard, ( 2003 ). Teori Organisasi dan Pengorganisasian, Jakarta,.PT Raja Grafindo Persada Sondang P. Siagian, ( 2003 ). Teori dan Praktek Kepemimpinan, Jakarta. PT Raja Grafindo Persada

Amin Wijaya Tunggal, ( 2004 ). Budaya Organisasi, Jakarta. Harvarindo

Triguno, ( 2004 ). Budaya Kerja, Jakarta. PT Golden Trayon Press

Husein Umar, ( 2000 ). Riset Sumber Daya Manusia, Jakarta. PT Gramedia Pustaka Utama

Yogi.MS, ( 2001 ). Metode Penelitian. Bandung

Cornelis Trihendra, ( 2005 ). SPSS 12, Statistik Inferen Teori dasra dan Aplikasinya, Jogjakarta.Andi Ofset.

Triantoro Safaria, ( 2004 ). Kempemimpinan. Jogjakarta. Garha Ilmu

Hasibuan, Melayu. SP, ( 2001 ). Manajemen Sumber Daya Manusia, Jakarta. PT.Bumi Aksara

Decler, Gary, ( 1997 ). Manajemen Sumber Daya Manusia, edisi Bahasa Indonesia, Jilid I, Jakarta.Prehalindo.

Bennis,Warren. ( 1997 ). Management People, edisi Bahasa Indonesia, Jakarta Elexmedia Komputindo / Gramedia

Djokosantoso Moelyono,( 2003 ). Beyond Leadership, Jakarta, Gramedia

Bacal, Robert, ( 1999 ). Performance Management, edisi Bahasa Indonesia, Jakarta, Gramedia Pustaka. Utama

Robbin, Stephen P.( 1990 ), Organization Theory, Struckture, Design and Application, Third edition, New Jersey, Prentice Hall,Inc 